\title{
Primate Retrovirus
}

National Cancer Institute

\section{Source}

National Cancer Institute. Primate Retrovirus. NCI Thesaurus. Code C14341.

An RNA containing virus infecting primates (SIV, ST LV, SFV). 